\title{
Analysing Character Education Values at SDIT Al-Qalam Through Song Lyrics
}

\author{
Fahmi Gunawan \\ Islamic State Institute of Kendari, \\ Southeast Sulawesi, Indonesia \\ fgunawanp@gmail.com
}

\author{
Zulaeha \\ Islamic State Institute of Kendari \\ Southeast Sulawesi, Indonesia
}

\begin{abstract}
Children learn through playing and chanting. Children's song lyrics can help building good characters in their early of age. They can feel the presence of song lyrics as a media for accompanying their play activities. This research aims at exploring character education values at al-Qalam Islamic Integrated School (SDIT), Kendari, Southeast Sulawesi, through song lyrics. Learning through chanting song lyrics such as menanam jagung (planting corn), lihat kebunku (see my garden), di sini senang di sana senang (we are happy here and there), anak gembala (shepherd children) has many recompenses. Some of them are enjoyable to learn and medium to drill moral values. The findings show that character education values through modification song lyrics are love, work ethic, diligent, cooperation, and discipline. In addition, those values are able to implement in children's daily life because of supported by school atmosphere which is based on character education.
\end{abstract}

Keywords-Character Building, Song Lyrics, Al-Qalam Integrated Islamic Primary School

\section{INTRODUCTION}

The occurrence of moral crisis in Indonesia is swelling quite rapidly for the past 20 years. It becomes alarming phenomena. Indonesia has been known as upholding ethics, decency, and dignity nation in the past, and almost lost of nation identity. This is one of the failures indicators in character and spiritual educations. Education has failed to construct positive character.On the other hand, selfishness, unawareness, belligerent, and vicious behavior become dominant in society. Hence, appropriate educational solutions are needed to prevail over these problems. One of the ways to overcome this problem is to get children's playing dan singing songs containing character education values (Rahmawati, 2010), (Nugrahanani, 2012).

Character education is everything conducted by teachers to help children understand, maintain, and behave in line with aplicable rule values (Lestari, 2012). Teachers play an pivotal role to shape children characters by examplifying both in behaving and well speaking (Soetari, 2014). Character education in early childhood becomes basic foundation in developing social skills (aquilar \& Tansini, 2012) and avoiding emergence of destructive attitude in the future (Rosmiati, 2014). Other research demonstrates that children with good moral character at an early age will be able to solve their problems better in adolescence and adulthood (Doty, 2006). Therefore, educators must be more creative in utilizing attractive, exciting, innovative learning method. Song lyrics are one of creative, innovative, interesting methods in learning foreign language (Lestari, 2012).
Songs of children are carefree songs which reflects noble ethic. They are commonly sung and usually done by children, by the lyrics contain simple things (Fabbri, 1982; McKay \& Fujinaga, 2006). Likewise, they discuss on how to love almighty God, others human being, parents, brother-sister, and beauty of nature. They are written in simple language in line with children's natural thought and can be utilized to formulate suggestion, persuasion, and educational or moral advice (Rosmiati, 2014). Moreover, children songs are one of the fascinating and exiting medias for children to get knowing environment surrounding them, particularly when they learn foreign language.

Through songs, children are able to learn many things. They will be happy to learn foreign language. Then, they become easy to understand teaching materials. In line with this, teachers' ability to select a song and to create motion ageappropriate child development will impact the success of learning foreign language process in early childhood.

There are several reasons why song lyrics become fascinating and interesting media. According to some studies, the writers found these rationales. Firstly, songs can stimulate a child's brain associated with reading, counting and developing emotional system of children (Salmon, 2010) so they can quickly memorize the letters. Here, songs are able to train children's memory as well (Ilari \& Gluschankof, 2009). Secondly, memory of children are accustomed and well honed through songs. Thirdly, they also help enlargement of children's social lives, such as working together in a team, and learning socialization. Fourthly, they are able to lead children to express their feelings and empathy. Fifthly, they can develop children's creativity from an early age (Samuelsson \& Carlsson, 2008; Niland, 2009). Children not only can create any item as a source of music for their toys but also they learn to sing, dance, move on, according to music being heard. Sixthly, songs can enrich spiritual life and provide a balance of life for children. Through songs, children can express their thoughts and feelings and control their emotional aspects (Miranti, Fitri, \& Hapsari, 2015). Seventhly, songs can be used as a medium for character building to children. Character building are required for imparting education, personality, moral children (Rosmiati, 2014). Ultimately, songs have an important role in children life (Gillespie \& Glider, 2010; Reunamo, et al, 2014).

Character building through songs is implemented by an Integrated Islamic School (SDIT) al-Qalam Kendari, Southeast Sulawesi. This school was chosen because its 
learning curriculum constantly incorporates national education curriculum-based on character education in every learning activities whether in class or outside of class. Hence, this school becomes the most favorite school in Kendari city.

The role of song lyrics in building character education has been extensively studied using various perspectives. Some studies argue about the role of song lyrics as a method of character education building (Lester, 2012; Azhar, 2009; (Widiyono, 2013), converse the role of song lyrics to learn foreign languages such as; Arabic (Zukhaira 2010; Hasan, 2016 ), English (Saricoban \& Metin, 2000; Paquette \& Rieg, 2008; Kovaleva \& Stakhova, 2014; Miranti, Engliana \& Hapsari, 2015), and Indonesian (Tyasrinestu, 2014). The studies used action research method (Rianita, et al, 2012; Barokatussolihah, 2016; Pulukadang and Laiya, 2012), and active learning method (Arifa \& Chamidah, 2012; Chasanah \& Hasibuan, 2014; Zahro, 2016, et al.). Therefore, this research was conducted to combine the previous studies result and research methods. Ultimately, there are two questions addressed in this research, first, to what extent the forms of song lyrics utilized at SDIT Al-Qalam in learning Arabic process; and second, how are character education values contained in song lyrics and their implementation to build character education for students at SDIT Al-Qalam.

\section{METHODS}

This research was descriptive qualitative. It held at SDIT al-Qalam, Kendari, Southeast Sulawesi, Indonesia. Its sources data were acquired from 3 teachers, 10 students, and 10 parents. Song lyrics utilized in learning Arabic process as the data used in this study. The data collection was conducted for three months by interviewing, observing, and studying documents. Contents analysis was conducted in data analysis.

\section{RESEARCH FINDINGS \& DISCUSSION}

Arabic language curriculum at SDIT Al-Qalam has been taught from year to year. Several teachers teach the course. The course for the first time was quite boring, unattractive, unpleaseant, because of less creativity applied in learning method. Yet, once the teacher utilized the song lyrics in the course, the situation gradually turned into attractive, creative, enjoyable learning, and didnot become a burden for all learners. The form of song lyrics sung in SDIT Al-Qalam is as follows.

\section{A. Song Lyrics Form Utilized in Learning Process}

In Arabic learning, every subject matter has its own song lyrics. There are a plenty of subject matters learnt in Arabic. In this research, the writers analyzed four songs only; namely menanam jagung (planting corn), lihat kebunku (see my garden), di sini senang di sana senang (here and there;we are happy), and anak gembala (the shepherd children).

In terms of discussing on color subject in Arabic, the teacher utilized song lyrics of menanam jagung (planting corn). This was due to its tempo, lyrics, and melody which was similar to the subject. Before teaching, initially, teacher taught song lyrics to the students. Having mastered the song lyric, then the teacher modified its song lyrics.For instance, the song lyrics, ayo kawan (come on friend); kita bersama (we were together); menanam jagung (planting corn); $d i$ kebun kita (in our garden) were modified to Arabic lyrics as the following example,سروال أسود celana hitam (black pants); ثوب أبيض baju yang putih (white shirt); رباط أزروق (b) dasi yang biru (blue tie); حذاء أسمر sepatu yang coklat (brown shoes).

Here, children were able to learn subject of color vocabulary with a very easy, fun, not boring, as modified in singing form. Those color presented were أسود hitam (black), أبيض putih (white), أزرق biru (blue), أسمر coklat (brown), أصفر kuning (yellow), أحمر merah (red), أخضر hijau (green).

This also happened in other song lyrics. Here, the teacher should be more creative to create some lyrics relating to Arabic vocabulary. Once the teachers would like to educate Arabic vocabulary, then they were able to utilize song lyrics from children songs. For instance, to train Arabic vocabularies dealing with family member, school equipment, and garments, the teachers were able to utilize song lyrics of lihat kebunku (see my garden); di sini senang di sana senang (here we are happy; there we are happy); and anak gembala (the shepherd children).

Here are the following example of those song lyrics, lihat kebunku (see my garden); di sini senang di sana senang (here we are happy; there we are happy); and anak gembala (the shepherd children). In Arabic teaching, teacher at primary school modified song lyric of lihat kebunku "see my garden" to family members in Arabic. The lyrics lihat kebunku (see my garden); penuh dengan bunga (full of flowers); ada yang putih (there is white flower); dan ada yang merah (and there is red flower) were altered to Arabic lyric أمي أحي ibuku (my mother); أبي أخي أبي (malahku (my father); saudariku (my sister). We can discover too the modification of song lyric disini senang di sana senang (here and there, we are happy) to school equipment. The lyrics $d i$ sini senang (here we are happy); di sana senang (there we are happy); dimana-mana hatiku senang (everywhere we are happy) are changed to نعل sandal (slipper); رباط dasi (tie); جورب itu kaos kaki (that is socks). This also happens to song lyrics of anak gembala (The shepherd children). The lyrics Aku adalah anak gembala (I am the children of shepherd); selalu riang serta gembira (always happy and fun); were modified to سروال celana (trousers); قميص kemeja (shirt); إزار sarung (sheath), قلنسوة peci (cap). If the teachers always give assignment to the student to sing those songs, they will contribute suggestion to children to have such kind of character education values dealing with the meaning of those songs.

B. Character Education Values through Song Lyrics and Its Implementation to Children Character at School.

The song lyrics as explaining before were regularly sung by students of SDIT Al-Qalam either inside or outside the classroom, even at their home. They learnt Arabic while playing and singing. They sang those songs everyday, everywhere and whenever they wanted. The songs can internalize within their selves and the children are able to 
implement education values within those songs. Even, the teachers at SDIT Al-Qalam inquired them to impelement the character education values in their daily life at school.

The lyric menanam jagung, for instance, reflects love to environment, work ethic, and diligent character. Those characters are not only spoken, but also practiced and applied in school daily life. Caring for environment is applied to green school condition. There is certain green house in school containing a wide variety of ornamental plants. It is compulsory to all new students to bring ornamental plants in the first day of the school. This creates school condition more comfortable, enjoyable, and interesting to learn. Work ethic character is implemented to voluntary work activities in every Friday. All students are asked to clean their own classroom, and teachers evaluate which class is the cleanest of all. It will be the champion and be awarded prizes. This creates school condition more comfortable, enjoyable, and interesting to learn. Hard-working character is implemented in competition of students' creations on cooking food and competition of food and drink bazaar between each class.

The lyric lihat kebunku (see my garden) reflects love to beauty and cleanliness of environment character. Those characters are implemented on Pendidikan Lingkungan Hidup (environmental education) subject. At school, it is obligatory for students to plant the seeds in polybag and observe how they grow by means of documentation. If the students break flower stalks, they will be adviced and summoned by vice principal not to show again their deeds and have to substitute the same flower as they break. When they intentionally and unintentionally broke flowerpot in playing, the principal immediately wrote letter to their parents to return the flowerpot back.

Additionally, this character is implemented in rule made by principle prohibiting students not to use shoes in classroom. They have to put their shoes on the place provided outside the class, and dispose their waste at selected places.The dumps are provided in each classroom, office, and certain places. Cleaning services are mandated on maintaining the cleanliness and the beauty of surroundings all time. That is why the school wins Adiwiya Mandiri prize as the second winner from all the elementary school and kindergarten at Kendari City. If Adiwiyata Mandiri competition comes, the principal will send a letter to all parents to bring polybag flowers which are ready to be planted. Each student must bring a flower.

In addition, they are also required to bring recycle goods, like car tires, gallons, bides, jars, basins, and buckets as flowerpot. To confirm this character, the school makes slogans related in every place. One of the slogans is satu sampah; seribu bencana (one garbage, thousand disasters). Furthermore, at the end of each semester, the school principal held a visiting gardens to coach the students directly how to plant and harvest fruits there. They are able to interact with the owner of garden and discuss everything about it, and freely consume the fruits.

The lyric di sini senang; di sana senang (we are happy here; we are happy there) reflects peace-loving and cooperation character. In the school, peace-loving character is implemented in conflict completion. As there are students hating and fighting each other, the teacher will immediately persuade them to be reconciled quickly. In addition, the teacher train to have cooperation character to the students. This character is applied to ornamental plants farm in flowerpot made from recycled materials such as tires, and household wastes. Besides, it is implemented to their scout and science activities as well. Each class has a scout and science activities once a week. The school was selected to represent primary schools throughout Southeast Sulawesi province to attend National Jamboree and science competition every year.

The lyric anak gembala (children of shepherd) reflects love to animals, diligently-working, have a high work ethic, and discipline. Those characters are implemented in every activities hold by school. Loving animals is applied to feed fish in their pond near to head master room. Diligently working is implemented to make creation from selected materials by the students, such as beams, fabric, and plastic. Work ethic is implemented to every competition hold by school. In addition, there is sport competition at the end of each semester. The students are asked to win the competition they conduct, such as tug of war, bola gotong (a traditional games by bringing ball together), volleyball, and football by having a good teamwork. Besides, the most important thing is discipline, which is implemented by attending school punctually starting at 07.00 a.m. unless students will get punishment, such as picking trash in a certain amount, cleaning school toilets, and mopping teacher room.

It has been claimed by philosophers, such as Martin Luther, Immanuel Kant, Friedrich Schiller, Herbert Read, Roger Sruton, Jean Jacques Rousseau that music can set a responsible, organized and rebust society. They stated that musics represent good and hence they were vital for fostering of moral personality. Musics were originally means for communicating morality and passions and establishing sound of morality as Plato recommended (Ko, 2010).

Hence, the important role of music in every field of life is undoubtable.In the history, song lyrics as a form of worship were conducted by Taize communities in Burgundy, France. They had been done as a form of communication to Almighty God (Anonymous, 2004), as well as sufi songs in Egypt, Turkey, and Iraq (Mustapha \& Mubarak, 2006; ), and as a means to unlock the treasures of divine truth (Ash'ari, 2007). In Indonesia, song lyrics have many functions. One of them is a medium for preaching Islamic teachings integrated with local culture, as Sunan Kalijaga (one of the nine leaders Pios) did (Johns, 1961; Van Djik, 1998). He shared Islamic teachings in Java through Javanese songs, such as "Song Rumekso Ing Wengi”, Iler-ilir, and song of Lingsir Wengi". (Ricci, 2014). Additionally, songs are able to become a medium for children building character (McKernon, 1979).

Song lyrics as a method of building character in education for children is not only found in Indonesia, but also in other countries. In China, the term character education is known as moral education which is based on Confucius 
teachings (Ho, 2003; Ko, 2010). In cultivating moral education for children, China's government placed heavy emphasis on traditional morality and modern socialism, such as the virtue of patriotism, civilized behavior, diligence, discipline, and selflessness (Ko, 2010). In addition, there is a special term in China 'Moral Education Seven Character Song' to build moral education. It means that each line of song lyrics consists of seven chinese characters which places a prominence on students conduct every day. Those characters are sense of community, nationhood, discipline, hardworking, strong moral values, patient, love, perseverance, responsibility, friendship, and hope (Ma, 2001).

As in China, character education in Israel is a term known as "social competencies" which is based on Jewish teachings. There is no study done on the role of song's lyric in the development of social competencies in Israel. But, there is few studies on the singing repertoire in early childhood. The ministry of education lately edited a four-volume collection of songs for children in Hebrew aiming at the common and high quality repertoire. The lyrics were chosen as its contribution to all fields, including social competencies (Gluschankof, 2008; Gluschankof \& Kenney, 2011).

Different to China dan Israel, building moral education through song lyrics in Russian is being done with unique manner. They are used to call it prazdniki and musical didactic games. Prazdniki means celebrations, holidays, or parties (Sinagatullin, 2001). For instance, in woman's day, teacher and children prepare mini poems, songs, and dances dedicated to mother and grandmother and emphasize the love of family and country (Holmes, 2014). Meanwhile, musical didactic games are exiting educational element of curriculum helping to develop problem solving skill for children (Ispa, 2002). On the other hand, children are not forced to think, remember, concentrate and they are not on task content accomplishment (Holmes, 2014).

Character education in the Middle East countries is known as tarbiyyatul akhlaq (moral education) which is based on Islamic teachings. Building character education for children is the most important and places heavy emphasis in Islam. But, there is not special songs dealing with it. We can find only how Islam educates moral values through hadits (prophet's sayings), quran (holy book), tafsir (exegeration), or even poem to the children. For instance, it is clearly stated in hadits that children in early age has to do prayer (Rew et all, 2004), even if they do not do prayer, they can get punishment (Gil'adi, 1992). This hadits enlightens us to have responsible character to our self and to our God. This is one of the examples of moral education in Islam (Fadlillah \& MK, 2013)

Even though the ways in integrating character values have different name, the contents of character education values in each country are fundamentally similar, whether in Indonesia, China, Israel, Russia, and or in Middle East. They confirmed the significance of cultivating character education values through song lyrics for children which are based on socio-cultural, religion, politics, environment background of each country. Ultimately, this research concludes that character education values through song lyrics modification conducted at SDIT al-Qalam Kendari, Southeast Sulawesi Indonesia are universal education values, such as love (including love to animal, environment; beauty and cleanliness, and peace), work ethic, dilligent, cooperation, and discipline. In addition, those characters are able to be implemented in children daily life since they are supported by school atmosphere which based on character education values.

\section{CONCLUSION}

A strong character education is the most important thing and must be built from the early age of child. It is intended to create an excellence private as national education goals. SDIT Al-Qalam as school-based character education in Kendari city, Southeast Sulawesi has a strategic and important role to develop positive character of children. Hence, teachers need to use creative and innovative methods. One of the methods is chanting as a part of children's life.

Chanting is utilized as a method due to its enjoyfull, excitement, happiness, and not to be bored. Teachers educate them chantings, such as menanam jagung (planting corn), lihat kebunku (see my garden), di sana senang di sini senang (here we are happy and there we are happy), anak gembala (children of shepherd) and modify them to Arabic vocabularies lingking with colors, family members, school equipments, and garments. If those chantings and song lyrics are frequently heard, then it is hoped that they are able to give suggestion to children to have such kind of good characters dealing with the meaning of those songs. Additionally, In addition, those characters are supported by school atmosphere which is based on character education values.

\section{REFERENCES}

[1] A. Gil'adi, Children of Islam: Concepts of Childhood in medieval Muslim society, Springer, 1992.

[2] A.H. Johns, "The role of Sufism in the spread of Islam to Malaya and Indonesia," Journal of the Pakistan Historical Society, vol. 9, pp. 143, (3) 1961.

[3] A. Niland, "The Power of Musical Play: The Value of Play-Based, Child Centered Curriculum in Early Childhood Music Education," General Music Today, vol. 23, pp. 17-21, (1) 2009.

[4] Anonim, "Spritualitas Taize: Inti Metode Penerapan Praktis Perjuangan dan Kontemplasi," INTIM: Jurnal STT Intim Makassar, pp. 79-81, 2004.

[5] A. Rosmiati, "Teknik Simulasi dalam Pendidikan Karakter Anak Usia Dini melalui Lirik Lagu Dolanan," Resital, vol. 15, pp. 71-82, (1) 2014.

[6] A. Salmon, "Using Music to Promote Children's Thingking and Enhance Their Literacy Development," Early Child Development and Care, vol. 180, pp. 937945, (7) 2010.

[7] A. Saricoban., and E. Metin, "Songs, Verse, and Games for Teaching Grammar," The Internet TESL Journal, vol. 6, (10) 2000.

[8] A.S. Mustapha., \& M. Z. Mubarak, "Dakwah melalui Muzik dan Nyanyian: Satu Perbincangan," Prosiding Seminar Serantau Dakwah dan Kesenian, Malaysia, pp. 101-105, 2006

[9] A.V. Holmes, "Music in The Russian Preschool Curriculum," Perspective, vol. 9, pp. 22-26, (3) 2014.

[10] Barokatussolehah, "Upaya Meningkatkan Penguasaan Mufradat Bahasa Arab melalui Metode Bernyanyi di 
Kelas VII A MTS Donomulyo Kulon Progo," Jurnal Pendidikan Madrasah, vol. 1, (1) 2016.

[11] B. Ilari., \& C. Gluschankof, "Music in The Early Years: Research, Theory and Practice," Early Child Development and Care, vol. 179, pp. 685-693, (6) 2009.

[12] C. Gluschankof, "Musical Expressions in Kindergarten: An Inter-Cultural Study?," Contemporary Issues in Early Childhood, vol. 9, pp. 317-327, (4) 2008.

[13] C. Gluschankof., S.H. Kenney, "Music literacy in an Israeli Kindergarten," General Music Today, vol. 25, pp. 45-49, (1) 2011.

[14] C. McKay., and I. Fujinaga, "Musical Genre Classification: Is It Worth Pursuing and How Can It Be Improved?," ISMIR, 2006.

[15] C.W. Gillespie, \& K. R. Glider, "Preschool Teachers' Use of Music to Scaffold Children's Learning and Behavior," Early Child Development and Care , vol. 180, pp. 799808, (6) 2010.

[16] E. Soetari, "Pendidikan Karakter dengan Pendidikan Anak untuk Membina Akhlak Islami," Jurnal Pendidikan Universitas Garut, vol. 8, pp. 116-147, (1) 2014.

[17] F. Fabbri, "A Theory of Musical Genres: Two Applications," Popular Music Perspective , 1982.

[18] F. Nugrahanani, "Reaktualisasi Tembang Dolanan Jawa dalam Rangka Pembentukan Karakter Bangsa (Kajian Semiotik),"Kajian Linguistik dan Sastra, vol. 24, pp. 5868, (1) 2012

[19] F. Tyasrinestu, "Lirik Musikal pada Lagu Anak Berbahasa Indonesia,” Resital, vol. 15, pp. 163-168, (2) 2014.

[20] Hasan, "Media Musik (Lagu) dalam Pembelajaran Bahasa Arab Tingkat MI," Jurnal Al-Maqoyis, vol. 4, (1) 2016.

[21] I. Miranti., Engliana, \& F.S. Hapsari, "Penggunaan Media Lagu Anak-Anak dalam Mengembangkan Kemampuan Kosa Kata Bahasa Inggris Siswa di PAUD,” Faktor Jurnal Ilmu Kependidikan, vol. 2, pp. 167-172, (2) 2015.

[22] I.M. Sinagatulin, "Expectant times: rural education in Russia," Educational Review, vol. 53, pp. 37-45, (1) 2001.

[23] I. N. Azhar., "Karakter Masyarakat Madura dalam SyairSyair Lagu Daerah Madura," Atavisme , vol. 12. pp. 217 227, (2) 2009.

[24] I. P. Samuelsson, \& M.A Carlsson "The Playing Learning Child: Towards a Pedagogy of Early Childhood," Scandinavian Journal of Educational Research, vol. 52, pp. 623-641, (6) 2008

[25] J. Doty, "Sports Build Character?," Journal of College and Character, vol. 7, pp. 1-9, (3) 2006.

[26] J. Reunamo., H-C. Lee, L-C., Wang., I Roukonen., T. Nikkola, \& S. Malmstrom, "Children's Creativity in Day Care," Early Child Development And Care, vol. 184, pp. 617-632, (4) 2014.

[27] J.M. Ispa, "Russian child care goals and values: From Perestroika to 2001," Early Childhood Research Quarterly, vol. 17, pp. 393-413, (3) 2002.

[28] K. R. Paquette., and S. A. Rieg, "Using Music to Support the Literacy Development of Young English Language Learners," Early Childhood Education Journal, vol. 36, pp. 227-232, (3) 2008

[29] K. Van Dijk, "Dakwah and Indigenous Culture: The Dissemination of Islam," Bijdragen tot de Taal-, Land-en Volkenkunde, vol. 154, pp. 218-235, (2) 1998.

[30] L. Rew., Y. J. Wong., R.W. Sternglanz, "The relationship between prayer, health behavior, and protective resources in school-age children," Issues in Comprehensive Pediatric Nursing, vol 27, pp. 245-255, (4) 2004
[31] M. Asy'ari., "Islam dan Seni," HUNAFA: Jurnal Studia Islamika, vol. 4, pp. 169-174, (2) 2007.

[32] M. Fadlillah., \& M.K, L, "Pendidikan Karakter Anak Usia Dini, ” Yogyakarta: Ar-Ruzz Media, 2013.

[33] N. Chasanah., \& R. Hasibuan, "Meningkatkan Kemampuan Bahasa Arab melalui Metode Pembelajaran Kooperatif Tipe Make A Match pada Kelompok A di RA An Nur," Jurnal Mahasiswa Teknologi , 2014.

[34] O. Kovaleva., \& K. Stakhova, "Lyrics of Popular Foreign Songs As a Source of Linguocultural Knowledge for a Foreign Language Immersion," General and Professional Education, vol 4, pp. 18-23, 2014.

[35] P. E. McKernon, "The development of first songs in young children," New Directions for Child and Adolescent Development, vol. 1979, pp. 43-58, (3) 1979.

[36] R. Aquilar., \& Tansini, "Join Analysis of Preschool Attendance and School Performance in The Short and Long Run," International Journal of Educational Development, vol. 32, pp. 224-231, (2) 2012.

[37] R. Lestari, "Nyanyian Sebagai Metode Pendidikan Karakter pada Anak," Prosiding Seminar Nasional Psikologi Islam, Surakarta, pp. 131-136, April 2012.

[38] R. Ricci, "Asian and Islamic crossings: Malay writing in nineteenth-century Sri Lanka," South Asian History and Culture, vol. 5, pp. 179-194, (2) 2014.

[39] S. Belkhyr, "Defining The Self and The Other in Disney Song Lyrics," International Journal of Human Sciences, vol. 10, pp. 1366-1378, (1) 2013.

[40] S. Ma, "Learning to be a Moral Person," Chinese Education and Society, vol. 34, pp. 74-77, (1) 2001

[41] S. N. Agung, "A Semantic Analysis of denotative Meaning in Kidung Doa Song By Sunan Kalijaga," Jurnal Ilmiah Bahasa dan Sastra, vol. 3, (1) 2016.

[42] T.C. Rianita., Muhaiban, \& A. M. Nasih, "Penggunaan Lagu Bahasa Arab untuk Meningkatkan Pemerolehan Kota Kata Bahasa Arab Siswa Kelas 5 MI Pesantren Sabiil Muttaqien Talunkulon Bandung Tulungagung," Jurnal Online, 2012.

[43] U.C. Zahro, "Penerapan Lagu Bahasa Arab dalam Pembelajaran Bahasa Arab dengan Metode Reciprocal Learning," Dialektika: Jurnal Pemikiran dan Penelitian Pendidikan Dasar, vol. 5, pp. 62-68, (1) 2016.

[44] W-C Ho, "Democracy, Citizenship and Extra-Musical Learning in Two Chinese Communities: Hongkong and Taiwan," Compare: A Journal of Comparative and International Education, vol. 33, pp. 155-171, (2) 2003.

[45] W-C. Ko., "Moral Education in China's Music Education: Development and Challenges," Internasional Journal of Music Education, vol. 28, pp. 71-87, (1) 2010.

[46] W. T. Pulukadang., \& S.W. Laiya, "Meningkatkan Pengenalan Kosa Kata Bahasa Inggris melalui Metode Gerak dan Lagu pada Anak Kelompok B di TK Pembina," Pedagogika, 2012.

[47] Y. Rahmawati, "The Role of Music in Character Building," The International Journal of Learning, vol. 17, pp. 61-76, (9) 2010.

[48] Y. Widiyono, "Nilai Pendidikan Karakter Tembang Campursari Karya Manthous," Jurnal Pendidikan Karakter, vol. 3, pp. 231-239, (2) 2013.

[49] Zukhaira, "Pengenalan Bahasa Arab melalui Nyanyian pada Anak Usia Prasekolah di TK Islam Mutiara Hati," Jurnal Abdimas Pengabdian Masyarakat, vol. 14, (1) 2010.

[50] Z. Arifa., \& D. Chamidah, "Pengembangan Bahan Ajar Qawaid Bahasa Arab Berbasis Mind Map untuk Tingkat Perguruan Tinggi,” El-Qudwah, 2012. 